\title{
PENINGKATAN KREATIVITAS PESERTA DIDIK \\ KELOMPOK B USIA 3-4 TAHUN MELALUI MEDIA \\ PLASTISIN TEPUNG DI PPT TUNAS MULIA \\ SURABAYA
}

\author{
ABSTRAK \\ INDAH WAHYUNINGSIH \\ PPT TUNAS MULIA, Surabaya \\ Indah.arsgirl@gmail.com
}

Dalam kegiatan membentuk dengan media plastisin lilin, peneliti menemukan permasalahan bahwa tingkat kreativitas anak belum optimal. Untuk itu peneliti berupaya menggunakan media plastisin tepung sebagai media alternatifnya. Tujuan penelitian adalah untuk meningkatkan kreativitas peserta didik kelompok B usia 3-4 tahun. Jenis penelitian yang digunakan adalah Penelitian Tindakan Kelas yang dilaksanakan dalam 2 siklus, setiap siklusnya dilakukan dalam 3 kali pertemuan. Teknik pegumpulan data diperoleh melalui observasi dan dokumentasi. Teknik analisis data menggunakan teknik deskriptif kuantitatif. Hasil penelitian menunjukan bahwa, setelah diberikan perlakuan mulai dari pratindakan, siklus 1 dan siklus 2 mengalami peningkatan dalam setiap indikator penilaiannya. Diperoleh rata-rata kelas saat pra-tindakan sebesar 43,9\%, kemudian mengalami peningkatan pada siklus 1 sebesar 53,8\%. Pada siklus 2 terjadi peningkatan secara signifikan hingga mencapai 80,3\% dan sudah masuk kategori Berkembang Sangat Baik (BSB) serta dianggap berhasil karena sudah melebihi ketentuan nilai 70\% dari jumlah anak yang berkategori baik. Dari hasil tersebut dapat disimpulkan bahwa melalui media plastisin tepung kreativitas peserta didik kelompok B usia 3-4 tahun di PPT Tunas Mulia Surabaya sudah berkembang sangat baik.

Kata kunci : Kreativitas, Anak Usia Dini, Plastisin Tepung

\section{ABSTRACT}

In wax plasticine activities, the researcher found a problem that the level of students' creativity was not optimal. He used teaching aids of plasticine wax as solution. This research aimed to increase the creativity of group B students aged 3-4 years. It used action research. It had 2 cycles. Each cycle had 3 meetings. Data collection techniques obtained observation and documentation. The result showed significant improvement after the students got cycle 1 and cycle 2.The data was as follows. Average class during pre-action was $43.9 \%$. Then, it increased $53.8 \%$ in cycle 1 . In cycle 2 , there was a significant effect, it increased up to $80.3 \%$. It included in the category of Very Good Development (BSB) and it considered that it was successful because it had exceeded the $70 \%$ value of the number of children in good category. Conclusion, the teaching aids of plasticine flour could increase the creativity of group B students aged 3-4 years at PPT Tunas Mulia Surabaya very well.

Keywords: Creativity, Early Childhood, Plasticine Flour 


\section{PENDAHULUAN}

Problem kehidupan yang penuh dengan tantangan dan persaingan menuntut kita untuk senantiasa mengoptimalkan berbagai potensi, diantaranya adalah potensi akal untuk dapat berfikir secara kreatif. Manusia harus mempunyai kreativitas dalam kehidupannya, karena dengan kreativitas diharapkan mampu memecahkan berbagai persoalan hidup secara efektif dan efisien. Menjadi pribadi yang kreatif tidaklah mudah ketika seseorang telah dewasa dan dihadapkan pada aneka permasalahan. Kreativitas memerlukan proses, oleh karena itu perlu digali, dimunculkan dan diasah semenjak dini. Para orangtua dan pendidiklah yang berperan untuk membantu mengoptimalkan potensi kreativitas anak-anak sejak dini, sebagai bekal bagi kehidupan mereka kelak. Munandar (1985); Nashori \& Mucharam ( 2002) mempercayai bahwa setiap anak itu kreatif. Apabila anak diberikan setumpuk buku, maka bisa menjadikan buku itu sebagai gedung, mobil, meja, kursi, dan lain sebagainya. Hal tersebut menunjukkan bahwa mereka mampu melihat sesuatu dengan sudut pandang yang berbeda dengan orang tua pada umumnya. Menurut Carl Rogers(1902-1987) dalam Munandar (2012:34) mengatakan bahwa tiga kondisi dari pribadi yang kreatif adalah: keterbukaan dalam pengalaman, kemampuan menilai situasi sesuai patokan pribadi seseorang (internal locus of evaluation), kemampuan bereksperimen, dan untuk "bermain" dengan konsep-konsep. Kreativitas akan muncul pada individu yang memiliki motivasi, imajinasi dan keingintahuan yang tinggi. Seseorang yang kreatif akan selalu mencari dan menemukan jawaban dari masalah yang mereka hadapi. Sikap terbuka terhadap sesuatu yang baru dan tidak diketahui sebelumnya tercermin juga pada dirinya. Mereka juga memiliki sikap yang lentur (fleksibel), tidak penurut, suka mengekspresikan diri dan bersikap natural (asli).

Kegiatan membentuk dan menghasilkan suatu karya melalui berbagai variasi bahan merupakan salah satu kegiatan anak dalam berkreasi di bidang seni. Melalui kegiatan tersebut anak dapat mengembangkan imajinasinya serta rasa percaya diri, sehingga kreativitas anak dapat berkembang dengan baik di masa golden age. Namun terkadang kreativitas anak dapat terhambat karena kurangnya latihan dan kesempatan dalam kegiatan membentuk sehingga mempengaruhi imajinasi dan antusias anak. Berbagai strategi dapat digunakan untuk mengoptimalkan kegiatan dalam berkreativitas yaitu dengan menggunakan media yang baik agar kreativitas anak dapat meningkat. Menurut Hasnidah (2015:36) mengatakan bahwa media dapat memberikan dampak positif bagi anak, baik yang berkenaan dengan proses perkembangan otak maupun yang berhubungan dengan kreativitas. Banyak media yang dapat digunakan guru dalam pembelajaran, guna mengembangkan dan menstimulus kreativitas anak, salah satunya adalah media plastisin tepung. Plastisin tepung merupakan media yang aman bagi anak dan mudah dalam pembuatannya, bahannya terdiri dari tepung, minyak, garam, pewarna makanan, essence makanan dan air. Plastisin tepung ini merupakan benda lunak yang dapat diremas, dipipih, dipilin, ditarik-tarik, ditekan-tekan, digulung-gulung sehingga dapat dibentuk sesuai dengan imajinasi dan keinginan anak. Anak dapat berkreasi bebas dengan membuat binatang, buah-buahan, bunga, mobil-mobilan dan sebagainya. Aspek perkembangan kreativitas dapat dikembangkan melalui kegiatan bermain plastisin tepung. Rachmawati \& Euis (2010:15) mengatakan bahwa kreativitas merupakan kemampuan seseorang untuk melahirkan sesuatu yang baru, baik berupa gagasan maupun karya nyata yang relatif berbeda dengan apa yang telah ada.

Menurut Eliyawati (2005:64) mengatakan bahwa Clay tepung merupakan salah satu alat permainan edukatif (APE), dikatakan APE karena clay dapat mengembangkan serta 
mendorong aktifitas dan kreativitas anak dalam aspek perkembangan anak. Clay dalam arti sesungguhnya adalah tanah liat, namun selain terbuat dari tanah liat, clay juga ada yang terbuat dari bermacam-macam bahan yang nantinya bisa dibuat aneka bentuk. Plastisin tepung dipilih karena bahan dasar pembuatan plastisin ini mudah didapat dan aman bagi anak. Pembuatannya tidak membutuhkan waktu lama. Tekstur dan warna dapat dibikin sesuai kehendak kita. Selain itu guru kelompok B. PPT Tunas Mulia belum pernah menggunakan media plastisin tepung sebagai media dalam pembelajaran terkait dengan kreativitas anak. Kelebihan plastisin tepung daripada plastisin lilin atau malam yaitu plastisin tepung teksturnya lebih empuk dibanding plastisin malam, karena dalam adonannya dapat dibuat sesuai dengan keinginan serta baunya harum seperti kue, sehingga anak diharapkan dapat lebih antusias mengapresiasi karyanya dengan baik dan juga aman bagi anak. Selain itu plastisin tepung tidak dapat berubah warna seperti pada plastisin malam yang lama-kelamaan akan berubah warna menjadi kecoklatan apabila plastisin malam tercampur dengan plastisin malam lain dan mudah mengeras, sehingga anak enggan memakainya kembali.

Berdasarkan pengalaman dan pengamatan di lapangan selama melakukan proses belajar mengajar di PPT Tunas Mulia Surabaya, peneliti melihat kreativitas anak belum muncul ketika diberikan kegiatan membentuk dengan media plastisin malam/lilin. Untuk itu peneliti berupaya menggunakan media plastisin tepung, sebagai media alternatif pembelajaran yang efektif, guna meningkatkan kreativitas anak. Menurut peneliti, dengan media plastisin tepung anak akan lebih antusias dan bisa leluasa membuat karya sesuai imajinasinya. Sejalan dengan hal tersebut, media plastisin tepung diharapkan dapat membantu guru dalam kegiatan belajar mengajar, membuat anak semakin antusias mengikuti kegiatan belajar mengajar serta menstimulus keluwesan dan kelancaran anak, serta orisinalitas dalam kegiatan membentuk. Penelitian dengan menggunakan media plastisin tepung dilakukan di PPT Tunas Mulia untuk meningkatkan kreativitas dan respon anak selama proses pembelajaran pada kegiatan inti yang terkait dengan tingkat kreativitas anak. Menurut Nursisto (1999: 6-7) kemampuan belajar siswa jadi lebih baik jika kemampuan kreativitasnya juga ikut dilibatkan. Pada dasarnya semua siswa memiliki kreativitas dalam dirinya yang harus dikembangkan, agar hidup menjadi semangat dan produktif.

\section{METODE PENELITIAN}

Penelitian ini merupakan penelitian deskriptif kuantitatif yang menggunakan desain penelitian tindakan kelas. Suharsimi Arikunto (2010:132) mengatakan bahwa penelitian tindakan kelas (PTK) adalah penelitian yang dilakukan dengan suatu pencermatan terhadap kegiatan belajar berupa sebuah tindakan yang sengaja dimunculkan dan terjadi dalam sebuah kelas secara bersama. Tujuan penelitian tindakan kelas ini yaitu meningkatkan kreativitas peserta didik melalui media plastisin tepung yang diterapkan pada peserta didik kelompok B di PPT Tunas Mulia. Subyek penelitiannya adalah peserta didik PPT Tunas Mulia Surabaya. Mereka adalah peserta didik dari rombel (rombongaan belajar) B yang berjumlah 11 anak, yang terdiri dari 5 anak perempuan dan 6 anak laki-laki. Teknik pengumpulan data yang dilakukan adalah observasi dan dokumentasi. 
Pada penelitian ini peneliti menganalisa data yang telah dilakukan dalam siklus I dan II dengan menggunakan teknik deskriptif kuantitatif persentase. Adapun rumus Ngalim Purwanto (2009) yang digunakan dalam penelitian ini adalah:

$$
\begin{aligned}
\mathrm{P}=\frac{f}{n} \times 100 \text { keterangan: } & \mathrm{f}: \text { frekuensi yang sedang } \\
& \text { dicari presentasinya } \\
\mathrm{n}: \text { jumlah frekuensi } & \mathrm{P}: \text { angka persentase }
\end{aligned}
$$

\section{HASIL DAN DISKUSI}

Sebagai langkah awal sebelum melakukan Penelitian Tindakan Kelas, peneliti melakukan pra-tindakan terlebih dahulu dengan tujuan untuk mengenalkan anak pada media plastisin serta menstimulus anak agar lebih tertarik dengan kegiatan membentuk. Dalam kegiatan tersebut anak diberikan kebebasan bermain sesuai dengan keinginan dan imajinasinya masing-masing. Dari perlakuan ini peneliti dapat melihat sejauh mana keberanian anak dalam berekspresi dan sekaligus dapat melihat tingkat keluwesan, kelancaran dan orisinalitas anak dalam membuat karya. Media yang digunakan saat melakukan pra-tindakan adalah media plastisin lilin/ malam. Hasil yang didapat belum optimal dan belum mencapai nilai keberhasilan. Kemudian dilanjut pada perlakuan berikutnya yaitu siklus 1 dan siklus 2 yang masing-masing siklus dilakukan selama tiga kali pertemuan. Media yang digunakan dalam kegiatan membentuk saat masuk pada siklus adalah media plastisin tepung. Dalam setiap perlakuan, apabila masih mengalami kekurangan-kekurangan, maka akan diperbaiki pada tindakan berikutnya hingga mencapai nilai keberhasilan yang diharapkan. Upaya yang dilakukan peneliti dalam penelitian tindakan kelas untuk peningkatan kreativitas melalui media plastisin tepung terhadap peserta didik kelompok B usia 3-4 tahun di PPT Tunas Mulia Surabaya tahun pelajaran 2018/ 2019 dengan melalui 2 siklus telah membawa hasil yang memuaskan bagi peneliti maupun guru teman sejawat. Hal ini bisa dibuktikan dari hasil penilaian tingkat kreativitas anak pada pra-tindakan, siklus 1 sampai siklus 2 sudah mencapai peningkatan secara optimal. Adapun hasil skor dan persentase yang didapat pada saat pra-tindakan, siklus 1 dan siklus 2 dapat disimpulkan pada tabel dan diagram dibawah ini

\section{Tabel 4.6}

Perbandingan hasil skor dan persentase peningkatan perkembangan kreativitas anak pada pra-tindakan, siklus 1 dan siklus 2

\begin{tabular}{|r|l|c|c|r|c|c|c|}
\hline \multirow{2}{*}{ No } & \multirow{2}{*}{$\begin{array}{l}\text { Nama } \\
\text { anak }\end{array}$} & \multicolumn{2}{|c|}{ Pra-tindakan } & \multicolumn{2}{c|}{ Siklus 1 } & \multicolumn{2}{c|}{ Siklus 2 } \\
\cline { 3 - 8 } & & Skor & \% & \multicolumn{1}{c|}{ Skor } & \% & Skor & \% \\
\hline 1 & R1 & 4 & $33,3 \%$ & 5 & $41,7 \%$ & 9 & $75 \%$ \\
\hline 2 & R2 & 5 & $41,7 \%$ & 6 & $50 \%$ & 9 & $75 \%$ \\
\hline 3 & R3 & 4 & $33,3 \%$ & 6 & $50 \%$ & 12 & $100 \%$ \\
\hline 4 & R4 & 7 & $58,3 \%$ & 8 & $66,7 \%$ & 11 & $91,7 \%$ \\
\hline 5 & R5 & 5 & $41,7 \%$ & 6 & $50 \%$ & 9 & $75 \%$ \\
\hline 6 & R6 & 5 & $41,7 \%$ & 6 & $50 \%$ & 8 & $66,7 \%$ \\
\hline 7 & R7 & 3 & $25 \%$ & 5 & $41,7 \%$ & 8 & $66,7 \%$ \\
\hline
\end{tabular}




\begin{tabular}{|r|c|c|c|r|c|c|c|}
8 & $\mathrm{R} 8$ & 4 & $33,3 \%$ & 5 & $41,7 \%$ & 8 & $66,7 \%$ \\
\hline 9 & $\mathrm{R} 9$ & 7 & $58,3 \%$ & 8 & $66,7 \%$ & 11 & $91,7 \%$ \\
\hline 10 & $\mathrm{R} 10$ & 7 & $58,3 \%$ & 8 & $66,7 \%$ & 11 & $91,7 \%$ \\
\hline 11 & R11 & 7 & $58,3 \%$ & 8 & $66,7 \%$ & 10 & $83,3 \%$ \\
\hline \multicolumn{2}{|r|}{ Rata-rata kelas } & $\mathbf{5 , 2 7}$ & $\mathbf{4 3 , 9 \%}$ & $\mathbf{6 , 4 5}$ & $\mathbf{5 3 , 8 \%}$ & $\mathbf{9 , 6 3}$ & $\mathbf{8 0 , 3 \%}$ \\
\hline
\end{tabular}

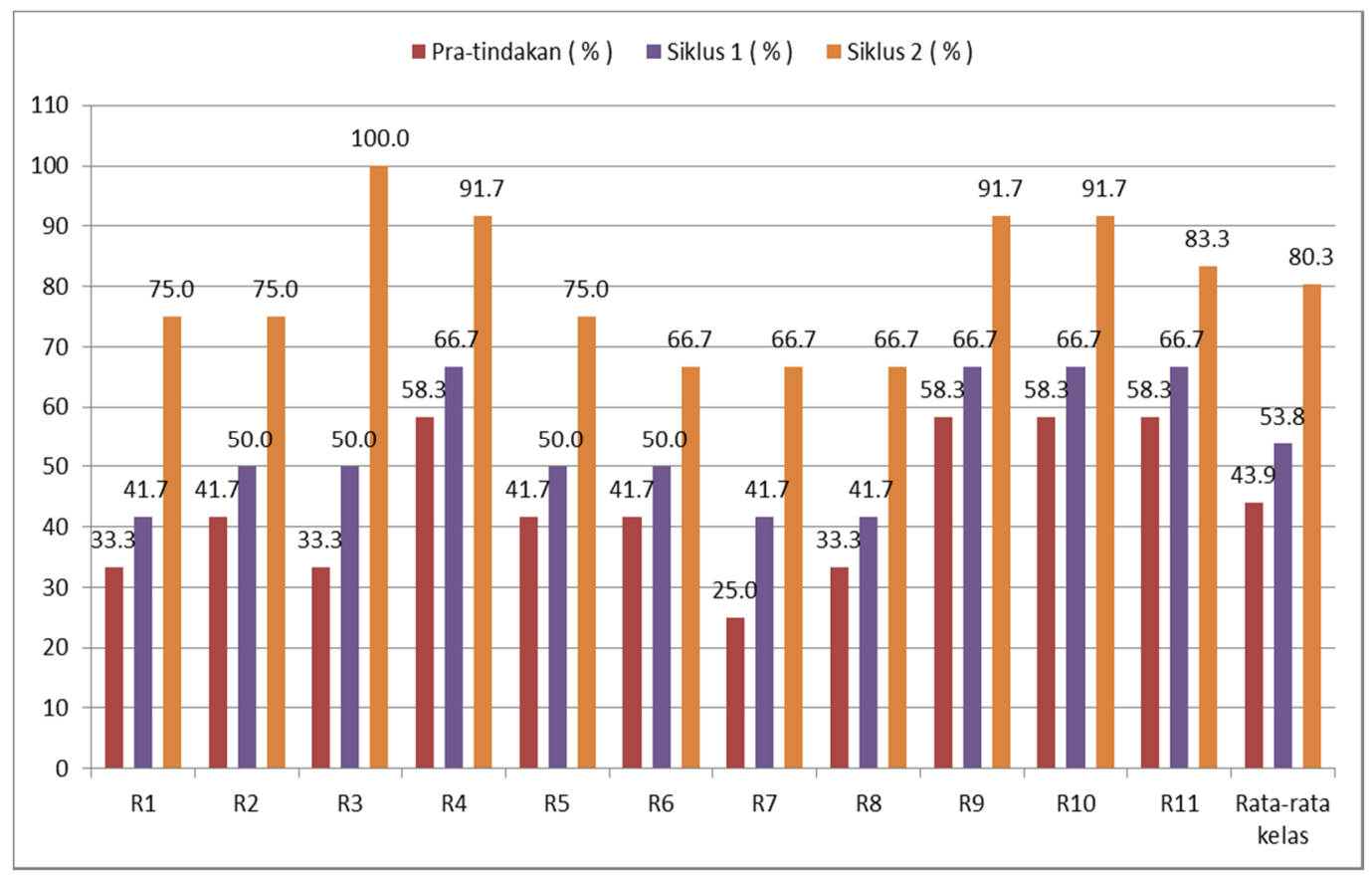

Gambar 4.4

Diagram perbandingan hasil persentase peningkatan perkembangan kreativitas anak pada pra-tindakan, siklus1 dan siklus 2

Dari diagram di atas dapat kita simpulkan tingkat kreativitas anak saat masih pratindakan masih mencapai $43,9 \%$. Kemudian pada siklus 1 mengalami peningkatan menjadi 53,8\%. Jadi dari pra-tindakan ke siklus 1 rentang kenaikan peningkatan kreativitas hanya 9,9\%. Dan dari nilai 53,3\% yang didapat pada siklus 1 tersebut belumlah mencapai nilai yang diharapkan. Dilanjutkan pada siklus 2 bisa terlihat ada peningkatan kembali secara signifikan dari 53,8\% pada siklus 1 menjadi 80,3\% pada siklus 2 . Sehingga rentang kenaikannya sangat pesat yaitu $26,5 \%$ dan nilai peningkatan pada persentase mencapai hingga $80,3 \%$. Kenaikan persentase ini dapat dikategorikan sudah mencapai perkembangan sangat baik yaitu Berkembang Sangat Baik (BSB) dan nilai tersebut dianggap sudah berhasil karena sudah melebihi ketentuan nilai $70 \%$ dari jumlah anak yang berkategori baik. Dari keberhasilan ini maka peneliti bisa menyimpulkan bahwa kreativitas anak dapat ditingkatkan melalui media plastisin tepung. Namun, dari observasi yang dilakukan peneliti selama melakukan penelitian tindakan kelas mulai dari perlakuan pra-tindakan, siklus 1 dan siklus 2 peneliti telah menemukan hal-hal yang dapat menunjuk pada peranan dan dampak penggunaan media plastisin tepung dalam peningkatan kreativitas anak usia 3-4 tahun di PPT Tunas Mulia Surabaya. Hal tersebut dapat terbukti saat anak diberikan perlakuan pada pra-tindakan dengan menggunakan plastisin malam jauh lebih antusias dan tertarik dengan 
menggunakan plastisin tepung yang mana teksturnya lebih empuk dan aroma harum yang membuat anak menyukainya. Peranan media plastisin tepung dalam penelitian tindakan kelas ini sangat penting sekali, karena dengan media plastisin tepung tersebut anak-anak bisa bermain dengan leluasa sesuai dengan imajinasi masing-masing anak tanpa merasa beban. Anak telah diberikan kebebasan dalam berkarya sekalipun masih dalam ketetapan tema saat pembelajaran, sehingga dapat memunculkan kreativitas anak dan anak akan lebih percaya diri juga merasa bangga serta optimis dengan kemampuan yang dimilikinya. Rasa takut salah serta rendah diri anak juga akan hilang apabila rasa percaya dirinya ditumbuhkan tanpa ada batas-batas dalam karyanya. Seperti yang disampaikan Nursito (1999: 109) pada pendapatnya bahwa berkembangnya anak untuk menggali kreativitas akan menjadikan anak percaya diri, mengurangi rasa takut, serta rendah diri. Apabila sudah timbul rasa percaya diri dan hilangnya rasa rendah diri maka anak menjadi optimis.

\section{PENUTUP}

\section{Kesimpulan}

Berdasarkan penelitian tindakan kelas yang telah dilakukan peneliti selama 2 siklus, dapat diperoleh kesimpulan yang menggambarkan bukti hasil deskriptif persentase ketuntasan belajar untuk meningkatkan kreativitas peserta didik kelompok B di PPT Tunas Mulia Surabaya. Dari kondisi pra-tindakan, siklus 1 dan siklus 2 telah mengalami peningkatan secara signifikan hingga mencapai $80,3 \%$ dengan nilai rata-rata kelas 9,63 yang menunjukkan bahwa media plastisin tepung dapat meningkatkan kreativitas anak dengan sangat baik. Hal ini dapat terlihat dari hasil nilai pada peningkatan kreativitas anak pada pra-tindakan sebesar 43,9\% pada siklus 1 sebesar 53,8\% dan peningkatan kreativitas pada siklus 2 sebesar 80,3\%. Dari data tersebut dapat menunjukan bahwa media plastisin tepung dapat meningkatkan kreativitas anak dengan hasil perkembangan Berkembang Sangat Baik (BSB).

\section{Saran}

Berdasarkan penelitian dan pembahasan tentang peningkatan kreativitas peserta didik kelompok B usia 3-4 tahun melalui media plastisin tepung di PPT Tunas Mulia Surabaya, maka saran yang bisa peneliti sampaikan adalah sebagai berikut:

Bagi Guru: 1) Media plastisin tepung dapat menjadi media alternatif yang bisa digunakan dalam proses pembelajaran untuk meningkatkan kreativitas anak dan cenderung lebih aman dibandingkan plastisin malam/lilin. 2) Dalam menumbuhkan kreativitas anak, guru tidak membatasi anak dalam berkreasi agar anak merasa bebas dan tidak terbebani dengan batasan-batasan sehingga anak bisa leluasa berkreasi sesuai dengan imajinasinya.

Bagi Kepala sekolah: 1) Hendaknya menyarankan kepada guru di lingkungan sekolah masing-masing untuk lain agar bisa membuat sendiri plastisin dari bahan tepung sehingga bisa digunakan dalam proses pembelajaran di kelas yang ramah dan aman bagi anak. 2) Membantu guru untuk mencarikan solusi dalam masalah pembelajaran. 
Bagi Orang Tua: 1) Oramg tua diharapkan dapat memberikan perhatian lebih pada setiap potensi yang dimiliki anak, tidak hanya terfokus pada potensi akademik semata namun juga pada potensi kreativitas anak. 2)Orang tua diharapkan dapat memberikan stimulus yang baik untuk meningkatkan kreativitas anak dengan menerapkan kegiatankegiatan dirumah yang menyenangkan dan bisa merangsang kreativitas anak.

\section{DAFTAR PUSTAKA}

Arikunto, S. 2010. Prosedur Penelitian Suatu Pendekatan Praktek. Jakarta: Rineka Cipta.

Asmawati, Luluk. 2017. Peningkatan Kreativitas Anak Usia Dini Melalui Pembelajaran Terpadu Berbasis Kecerdasa Jamak. Jurnal Pendidikan Usia Dini, Universitas Sultan Ageng Tirtoyoso, tersedia dilaman:

http://journal.unj.ac.id/unj/index.php/jpud/article/download/2556/1959/ (diunduh 21 Januari 2019)

Eliyawati, Cucu. 2005. Pemilihan dan Pengembangan Sumber Belajar Untuk Usia Dini. Jakarta. Depdiknas.

Hasnida. 2015. Media Pembelajaran Kreatif Mendukung Pembelajaran Pada Anak Usia Dini. Jakarta. PT Luxima Metro Media.

Munandar,S.C.Utami.1985. Mengembangkan Bakat dan Kreativitas Anak Sekolah. Jakarta: PT Gramedia Widiasarana.

Nashori, Fuad dan Rachmy Diana Mucharam. 2002. Mengembangkan Kreativitas Dalam Perspektif Psikologi Islam.Yogyakarta: menara kudus

Nursisto. 1999. Kiat Menggali Kreativitas. Yogyakarta: Mitra Gama Media.

Purwanto, Ngalim. 2009. Evaluasi Hasil Belajar. Yogyakarta: Pustaka Pelajar

Rahmawati, Yeni dan Euis Kurniati. 2010. Strategi Pengembangan Kreativitas Pada Anak Usia Taman Kanak-kanak. Jakarta: Kencana Prenada Media Group. 